\title{
Dampak Latihan Intensitas Berat pada Fungsi Imun Tubuh
}

\author{
Hayati \\ Tenaga Pengajar Prodi. Kepelatihan dan Olah Raga Universitas PGRI Adi Buana Surabaya
}

\begin{abstract}
Abstrak
Pemberian rangsang fisik berulang pada tubuh dapat menyebabkan proses adaptasi yang mencerminkan peningkatan kemampuan fungsional tetapi jika besarnya rangsangan tidak cukup untuk proses pembebanan, maka tubuh tidak akan mengalami proses adaptasi.Sebaliknya jika rangsang terlalu besar yang tidak dapat ditoleransi oleh tubuh akan menyebabkan jejas dan mengganggu keadaan homeostasis pada sistem tubuh. Latihan intensitas tinggi dapat meningkatkan hormone epinephrine dan cortisol di plasma yang dikenal sebagai efek immunomodulator

Dampak negatif dari latihan akan muncul khususnya pada latihan intensitas berat, seperti penurunan sistem imun sehingga seorang atlet akan lebih gampang mengalami infeksi.

Kejadian infeksi pada para atlet yang sedang dalam pemusatan latihan sudah banyak dilaporkan berdasarkan penelitian yang sudah dilakukan sebelumnya, tetapi masih belum jelas aspek-aspek ilmiah manakah yang paling merusak sistem imun dan lebih rentan terhadap infeksi. Jadi respon imun pada tubuh sebagai akibat dari latihan belum diketahui dengan jelas.

Beberapa hasil penelitian belum ada kesepakatan mengenai beban dan bentuk latihan fisik yang meningkatkan atau menurunkan ketahanan tubuh. Secara umum penelitian menunjukkan bahwa latihan fisik intensitas tinggi menimbulkan kerusakan respon ketahanan tubuh, sedangkan pada laihan intensitas sedang belum ada kesepakatan dalam kesamaan hasil terhadap respon imun.
\end{abstract}

Kata kunci : latihan intensitas berat, sistem imun

\section{PERMASALAHAN}

Sekarang ini pemerintah sedang berupaya untuk mensukseskan program memasyarakatkan olahraga dan mengolahragakan masyarakat karena dengan berolahraga banyak dampak positif yang didapat. Olaharaga dapat dibedakan menjadi olahraga rekreasi dan olahraga prestasi. Olahraga prestasi menjadi penting karena olahraga dapat mengangkat gengsi suatu negara. Dewasa ini dapat kita saksikan bagaimana suatu negara berlomba-lomba melakukan pembinaan secara serius pada para elit atletnya dalam menghadapi suatu pertandingan. Pertandingan mulai tingkat regional sampai internasional begitu banyak yang diadakan sehingga ilmu kesehatan olahraga akhirakhir ini berkembang sangat pesat.

Sebagian besar adaptasi dan respon fisiologi terhadap latihan dan pelatihan merupakan contoh pengaturan umpan balik negatif yang membantu tubuh meminimalkan perubahan keseimbangan selama latihan (Lamb,1984)..

Latihan merupakan rangsangan yang menyebabkan terjadinya gangguan pada homeostasis dan merubah lingkungan fisik dan kimia sel. Latihan menyebabkan suhu tubuh meningkat, keasaman darah meningkat, kandungan $\mathrm{O}_{2}$ di cairan tubuh berkurang, $\mathrm{CO}_{2}$ meningkat dan lain-lain. Satu atau lebih perubahan lingkungan internal tubuh dimulai dari sel tubuh (reseptor) yang kemudian menstimulasi jalur respon kompleks. Jalur ini menyebabkan perubahan aktifitas saraf (jalur saraf), perubahan di hormon (jalur hormon) dan perubahan pada organ khusus (jalur instrinsik) (lamb, 1984).

Saat akan menghadapi pertandingan khususnya pertandingan berskala internasional seorang atlet akan dipersiapkan dengan sangat serius. Program latihan yang baku sudah tersusun 5-6 x seminggu, malah kadang mereka harus melakukan latihan pagi dan sore hari saat mereka sedang dalam pusat pelatihan (trainning center ). Menghadapi hal tersebut kadang kala dampak negatif dari latihan akan muncul khususnya pada latihan intensitas berat, seperti penurunan sistem 
imun sehingga seorang atlet akan lebih gampang mengalami infeksi. Kejadian infeksi pada para atlet yang sedang dalam pemusatan latihan sudah banyak dilaporkan, contohnya pada penelitian oleh Spence tahun 2007 yang membandingkan kejadian infeksi saluran pernapasan pada atlet profesional yang sedang mengikuti kompetisi dengan orang yang kurang aktif dan atlet olahraga rekreasi ,yang diambil hapusan nasopharyng dan pharingnya menunjukkan bahwa kasus kejadian infeksi lebih sering terjadi pada atlet profesional dan kelompok yang tidak aktif dibanding pada atlet rekreasi.Beberapa penelitian yang pernah dilakukan menunjukkan bahwa insiden infeksi saluran pernapasan meningkat pada atlet yang melakukan latihan intensitas berat seperti :

1. Niemen, 1990 pada 2311 atlet maraton yang sedang mengikuti pertandingan di Los Angeles 12,9 \% dilaporkan mengalami infeksi saluran pernapasan dibandingkan dengan kelompok kontrol.

2. Peter dan batemen ( 1983) pada 150 peserta di Two Oceans Ultra Marathon ( $56 \mathrm{Km})$ di afrika Selatan menunjukkan insiden 33,3\% dibandingkan 15,3\% kelompok kontrol

3. Linde ( 1987 ) 44 atlet profesional Danish Orienteers diamati selama setahun dan menunjukkan hasil pada kelompok atlet episode infeksi 2,5/tahun dibanding 1,7 episode/tahun pada kelompok kontrol

4. Heath et al ( 1991) pada kelompok atlet lari $32 \mathrm{~km} / \mathrm{minggu}$ mengalami infeksi dua kali lebih sering dibandingakan pada kelompok atlet lari yang menempuh jarak $<778 \mathrm{~km} / \operatorname{tahun}$ dan 3 kali lebih sering pada atlet lari yang menempuh jarak > $1384 \mathrm{~km} /$ tahun.

Mekanisme terjadinya infeksi pada atlet profesional dengan tingkat intensitas latihan berat dapat dijelaskan melalui beberapa penelitian berikut ini. Beberapa penelitian telah melaporkan bahwa latihan dapat membawa respon akut yang hampir sama dengan respon akut pada sepsis dan trauma. Pada penelitian yang dilakukan oleh Bente tahun 2000 didapatkan bahwa latihan dengan intensitas berat meningkatkan level sitokin , dalam hal ini TNF- $\alpha$, IL-1, IL-6, IL-1 reseptor antagonis, TNF reseptor, IL-10,IL-8 dan macrophage inflammatory protein -1.IL6 pada saat istirahat lebih banyak diproduksi oleh otot lurik dan juga memiliki efek sebagai growth factor.Suzuki,2002 dalam penelitiannya juga menunjukkan bahwa latihan dengan intensitas berat juga meningkatkan mobilisasi netrofil dan monosit sehingga sitokin sebagai mediator dalam hal ini akan meningkat pada sirkulasi. Penelitian sejenis sudah sangat banyak dilakukan dan memiliki hasil yang sama tentang efek latihan intensitas berat terhadap peningkatan kadar sitokin.

Pemberian rangsang fisik yang berulang pada tubuh akan menyebabkan proses adaptasi yang dapat mencerminkan peningkatan kemampuan fungsional tetapi jika besarnya rangsangan tidak cukup untuk proses pembebanan, maka tubuh tidak akan mengalami proses adaptasi.Sebaliknya jika rangsang terlalu besar yang tidak dapat ditoleransi oleh tubuh akan menyebabkan jejas dan mengganggu keadaan homeostasis pada sistem tubuh (Setyawan,1995;96)

Sehubungan dengan pengaruh latihan terhadap konsentrasi darah putih sebagai parameter deteksi peningkatan sistem imun dalam tubuh, Nieman (1994) menyatakan bahwa latihan fisik tingkat sedang merangsang sistem imun, tetapi latihan fisik yang insentif dapat menyebabkan penurunan sistem imun. Tetapi masih belum jelas aspek-aspek ilmiah manakah yang paling merusak sistem imun dan lebih rentan terhadap infeksi. Jadi respon imun pada tubuh sebagai akibat dari latihan belum diketahui dengan jelas.Latihan yang digunakan oleh nieman adalah latihan treadmill selama 45 menit dengan intensitas tinggi $(80 \%$ VO2 max) dan intensitas sedang ( $50 \%$ VO2 max ).

Beberapa hasil penelitian belum ada kesepakatan mengenai beban dan bentuk latihan fisik yang meningkatkan atau menurunkan ketahanan tubuh. Secara umum penelitian menunjukkan bahwa latihan fisik intensitas berat menimbulkan kerusakan respon ketahanan tubuh, sedangkan pada latihan intensitas sedang belum ada kesepakatan dalam kesamaan hasil terhadap respon imun (Mackinon, 1992;53 )

\section{PEMBAHASAN}

Dosis latihan meliputi durasi, jarak, repetisi (volume), beban dan kecepatan 
(intensitas) dan frekuensi (densitas) (Bompa, 1994).

\section{Volume Latihan}

Volume latihan sering juga disebut sebagai durasi latihan yang meliputi bagianbagian berikut ini yaitu waktu atau durasi latihan, jarak tempuh atau beban yang diangkat perunit waktu dan jumlah repetisi. Untuk lebih mengakurasikan volume latihan perlu dipilih satuan pengukuran yang tepat. Untuk beberapa cabang olahraga seperti berlari, kano, ski lintas alam dan mendayung satuan berupa jarak, untuk angkat berat satuan berupa beban dalam kilogram. Dalam banyak cabang olahraga untuk menunjukkan volume secara lebih jelas digunakan 2 unit pengukuran seperti lari $12 \mathrm{~km}$ dalam 60 menit (Bompa,1994).

\section{Intensitas Latihan}

Intensitas latihan menunjukkan komponen kualitatif dari kerja yang dilakukan dalam periode waktu tertentu sehingga semakin banyak kerja yang dilakukan perunit waktu semakin tinggi intensitasnya.

Tabel 1. Skala Intensitas pada Olahraga Kecepatan dan Kekuatan (dikutip dari Bompa, 1994)

\begin{tabular}{|c|c|c|}
\hline $\begin{array}{c}\text { Nomor } \\
\text { Intensitas }\end{array}$ & $\begin{array}{c}\text { Prosentase } \\
\text { penampilan } \\
\text { maksimum }\end{array}$ & Intensitas \\
\hline 1 & $30-50 \%$ & Ringan \\
\hline 2 & $50-70 \%$ & Sedang \\
\hline 3 & $70-80 \%$ & Menengah \\
\hline 4 & $80-90 \%$ & Submaksimal \\
\hline 5 & $90-100 \%$ & Maksimal \\
\hline 6 & $100-105 \%$ & Supermaksimal \\
\hline
\end{tabular}

Tabel 2. Empat Zona Intensitas berdasarkan Reaksi Denyut Nadi Terhadap Beban Latihan (dikutip dari Bompa,1994)

\begin{tabular}{|c|c|c|}
\hline Zona & $\begin{array}{c}\text { Tipe } \\
\text { Intensitas }\end{array}$ & Denyut Nadi/menit \\
\hline 1 & Rendah & $120-150$ \\
\hline 2 & Sedang & $150-170$ \\
\hline 3 & Tinggi & $170-185$ \\
\hline 4 & Maksimal & $>185$ \\
\hline
\end{tabular}

Sebagian besar adaptasi dan respon fisiologi terhadap latihan dan pelatihan merupakan contoh pengaturan umpan balik negatif yang membantu tubuh meminimalkan perubahan keseimbangan selama latihan (Lamb,1984).

Latihan merupakan rangsangan yang menyebabkan terjadinya gangguan pada homeostasis dan merubah lingkungan fisik dan kimia sel. Latihan menyebabkan suhu tubuh meningkat, keasaman darah meningkat, kandungan $\mathrm{O}_{2}$ di cairan tubuh berkurang, $\mathrm{CO}_{2}$ meningkat dan lain-lain. Satu atau lebih perubahan lingkungan internal tubuh dimulai dari sel tubuh (reseptor) yang kemudian menstimulasi jalur respon kompleks. Jalur ini menyebabkan perubahan aktifitas saraf (jalur saraf), perubahan di hormon (jalur hormon) dan perubahan pada organ khusus (jalur instrinsik) (lamb, 1984).

\section{Sistem Imun}

Imunitas adalah resistensi terhadap penyakit terutama infeksi. Gabungan sel, molekul dan jaringan yang berperan dalam resistensi terhadap infeksi disebut system imun. Reaksi yang dikoordinasi sel-sel, molekul-molekul dan bahan lainnya terhadap mikroba disebut respon imun. Sistem imun diperlukan tubuh untuk mempertahankan keutuhannya terhadap bahaya yang ditimbulkan berbagai bahan dalam lingkungan hidup.

\section{Pembagian Sistem Imun}

Imunitas adalah resistensi terhadap penyakit terutama infeksi. Gabungan sel, molekul dan jaringan yang berperan dalam resistensi terhadap infeksi disebut sistem imun. Reaksi yang dikoordinasi sel-sel, molekul-molekul dan bahan lainnya terhadap makroba disebut respon imun. Sistem imun diperlukan tubuh untuk mempertahanan keutuhannya terhadap bahaya yang ditimbulkan berbagai bahan dalam lingkungan hidup.

Sistem imun dapat dibagi menjadi system imun alamiah atau nonspesifik/ natural/ innate/ native/ nonadaptif dan didapat atau spesifik/ adaptif/ acquired.Mekanisme imunitas spesifik timbul atau bekerja lebih lambat disbanding imunitas nonspesifik. Antara kedua sistem tersebut terjadi kerjaama yang erat, yang satu tidak dapat dipisahkan dari yang lain.

Pembagian system imun dalam system imun nonspesifik dan spesifik hanya 
dimaksudkan untuk memudahkan pengertian saja. Sebenarnya antara kedua system tersebut terjadi kerjasama yang erat, yang satu tidak dapat dipisahkan dari yang lain.

\section{A. Sistem Imun Non Spesifik}

Imunitas non spesifik fisiologis berupa komponen normal tubuh, selalu ditemukan pada individu sehat dan siap mencegah mikroba masuk ke tubuh dan dengan cepat menyingkirkannya. Jumlahnya dapat ditingkatkan dengan infeksi. Disebut non spesifik karena tidak ditujukan pada mikroba tertentu, telah ada dan siap berfungsi sejak lahir. Sistem tersebut merupakan pertahanan terdepan dalam menghadapi serangan berbagai mikroba dan dapat memberikan respon langsung.

\section{Sistem imun non spesifik dapat berupa : a. Pertahanan fisik/mekanik}

Dalam system pertahanan fisik atau mekanik, kulit, selaput lender, silia saluran napas, batuk dan bersin, merupakan garis pertahanan terdepan terhadap infeksi. Keratinosit dan lapisan epidermis kulit sehat dan epitel mukosa yng utuh tidak dapat ditembus kebanyakan mikroba.

\section{b. Pertahanan Biokimia}

Kebanyakan mikroba tidak dapat menembus kulit yang sehat, namun beberapa dapat masuk tubuh melalui kelenjar sei efek sebaseus dan folikel rambut. $\mathrm{PH}$ asam, keringat dan sekresi sebaseus, berbagai asam lemak yang dilepas kulit mempunyai efek denaturasi terhadap protein membrn sel sehingga dapat mencegah infeksi yang dapat terjadi melalui kulit. Lisozim dalam keringat, ludah dan air mata dan air susu ibu, melindungi tubuh terhadap berbagai kuman gram positif oleh karena dapat menghancurkan lapisan poptidoglikan dinding bakteri. Air susu ibu juga mengandung laktooksidase dan asam neuraminik yang mempunyai sifat anti bacterial terhdap E.koli dan stafilokokus. Asam hidroklorida dalam lambung enzim protolitik, antibody dan empedu dalam usus halus membantu menciptakan lingkungan yang dapat mencegah infeksi banyak mikroba.

\section{c. Pertahanan Humoral}

Sistem imun non spesifik menggunakan berbagai molekul larut yang diproduksi di tempat infeksi atau cedera dan berfungsi local. Molekul tersebut antara lain adalah peptide anti mikroba seperti defensin, katelisidin dan IFN dengan efek anti viral. Factor larut lainnya diproduksi di tempat yang lebih jauh dan dikerahkan ke jaringan sasaran melalui sirkulasi seperti komplemen dan protein Fase Akut.

\section{c.1. komplemen}

Berbagai bahan dalam sirkulasi seperti lektin, interferon, CRP dan komplemen berperan dalam pertahanan humoral. Serum normal dapat memusnahkan dan menghancurkan berbagai bakteri gram negative atas kerjasama antara antibody dan komplemen yang ditemukan dalam serum normal. Komplemen rusak pada pemanasan $56^{\circ} \mathrm{C}$ selama 30 menit.

Komplemen terdiri atas sejumlah besar protein yang bila diaktifkan akan memberikan proteksi terhadap infeksi dan berperan dalam proses inflamasi. Komplemen dengan spectrum aktivitas yang luas diproduksi oleh hepatosit dan monosit dan dapat diaktifkan secara langsung oleh mikroba atau produknya (jalur alternative, klasik dan lektin). Komplemen berperan sebagai opsonin yang meningkatkan fagositosis, sebagai factor kemotatik dan juga menimbulkan destruksi/ lisis bakteri dan parasit.

\section{c.2. protein fase Akut}

Selama fase akut infeksi terjadi perubahan pada kadar beberapa protein dalam serum yang disebut APP, bahn anti microbial dalam serum yang meningkat dengan cepat setelah system imun nonspesifik diaktifkan. Protein yang meningkat atau menurun selama fase akut disebut juga APRP yang berperan dalam pertahanan dini. Hati merumpapakan tempat sintesis APRP. Sitokin, TNF- $\alpha$, IL-1, IL-6 merupakan sitokin proinflamasi dan berperan dalam induksi APRP.

\section{c.3. C Reactive Protein}

CRP yang merupakan salah satu PFA termasuk golongan protein yang kadarnya dalam darah meningkat pada infeksi akut, sebagai respon imunitas nonspesifik. Sebagai opsonin CRP mengikat berbagai mikroorganisme, protein $\mathrm{C}$ pneumokok yang membentuk kompleks dan mengaktifkan komplemen jalur klasik. Pengukuran CRP 
digunakan untuk menilai aktivitas inflamasi. CRP dapat meningkat 100x atau lebih dan dengan bantuan $\mathrm{Ca} 2+$ dapat mengikat berbagai molekul antara lain fosforikolin yang ditemukan pada permukaan bakteri/jamur. Sintesis CRP yang meningkat meninggikan viscositas plasma dan laju endap darah. Adanya CRP yang tetap tinggi menunjukkan infeksi persisten.

\section{c.4. Lektin}

Lektin/ kolektin merupakan molekul larut dalam plasma yang dapat mengikat manan/manosa dalam polisakarida, karenanya disebut MBL yng merupakan permukaan banyak bakteri seperti galur pneumokok dan banyak mikroba tetapi tidak pada sel vertebrata. Leptin berperan sebagai opsonin, mengaktifkan komplemen. SAP mengikat lipopolisakarida dinding bakteri dan berfungsi sebagai reseptor untuk fagosit.

\section{c.5. Protein fase akut lain}

Protein fse akut yang lain adalah a1-anti tripsin, ameloid serum A, haptoglobin, C9, factor $\mathrm{B}$ dan fibrinogen yang juga berperan pada peningkatan laju endap darah akibat infeksi, namun dibentuk jauh lebih lambatdibanding CRP. Secara keseluruhan respon fase akut memberian efek yang menguntungkan melalui peningkatan resistensi penjamu, mengurangi cedera jaringan dan meningkatkan resolusi dan perbaikan cedera inflamasi.

\section{c.6. Mediator asal fosfolipid}

Metabolisme fosfolipid diperlukan untuk produksi PG dan TLR. Keduanya meningkatkan respon inflamasi melalui peningkatan permeabilitas vascular dan vasodilatasi.

\section{c.7. Sitokin IL-1, IL6, TNF- $\alpha$}

Selama terjadi infeksi, produk bakteri seperti LPS mengaktifkan makrofag dan sel lain untuk memproduksi dan melepas berbagai sitokin seperti IL-1 yang merupakan pirogen endogen, TNF- $\alpha$ dan IL-6. Pirogen adalah bahan yang menginduksi demam yang dipacu baik oleh faktor eksogen (endotoksik asal bakteri gram negatif ) atau endogen seperti IL-1 yang diproduksi makrofag dan monosit. Ketiga sitokin tersebut disebut sitokin proinflamasi, merangsang hati untuk mensintesis dan melepas sejumlah protein plasma seperti protein fase akut antara lain CRP yang dapat meningkat 1000 kali.

\section{d. Pertahanan Seluler}

Fagosit, sel NK, sel mast dan eosinofil berperan dalam system imun nonspesifik seluler. Sel-sel system imun tersebut dapat ditemukan dalam sirkulasi atau jaringan. Contoh sel dalam sirkulasi adalah neurofil, eosinofil, basofil, monosit, sel $\mathrm{T}$, sel $\mathrm{B}$, sel NK, sel darah merah dan trombosit. Sel tersebut dapat mengenal produk mikroba essensial yang diperlukan untuk hidupnya. Contoh sel dalam jaringan adalah eosinofil, sel mast, makrofag, sel T, sel plasma dan sel NK.

\section{B. Sistem Imun Spesifik}

Berbeda dengan system imun nonspesifik, system imun spesifik mempunyai kemampuan untuk mengenal benda yang dianggap asing untuk dirinya. Benda asing yang pertama kali terpajan dengan tubuh segera dikenal oleh system imun spesifik. Pajanan tersebut menimbulkan sensitasi, sehingga antigen yang sama dan masuk tubuh untuk kedua kalinya akan dikenal lebih cepat dan kemudian dihancurkan. Untuk meghancurkan benda asing yang berbahaya bagi tubuh, system imun spesifik dapat bekerja tanpa bantuan system imun nonspesifik. Namun pada umumnya terjalin kerjasama yang baik antara system imun spesifik dan nonspesifik seperti antara komplemen fagosit- antibody dan antara makrofag-sel T. Sistem imun spesifik terdiri dari system humoral dan seluler. Pada imunitas humoral, sel B melepas antibody untuk menyingkirkan mikroba ekstraseluler. Pada imunitas seluler, sel $\mathrm{T}$ mengaktifkan makrofag sebagai efektor untuk menghancurkan mikroba atau mengaktifkan sel CTC/Tc sebagai efektor yang menghancurkan sel terinfeksi.

\section{A. Sistem Imun spesifik Humoral}

Pemeran utama dalam system imun spesifik humoral adalah limfosit $B$ atau sel $B$. Humor berarti cairan tubuh. Sel B berasal dari sel asal multipoten di sumsum tulang. Sel B yang dirangsang oleh benda asing akan berproliferasi, berdiferensiasi dan berkembang menjadi sel plasma yang memproduksi antibody. Antibodi yang 
dilepas dapat ditemukan dalam serum. Fungsi utama antibody ialah pertahanan terhadap infeksi ekstraseluler, virus dan bakteri serta menetralkan toksinnya.

\section{B. Sistem Imun Spesifik seluler}

Limfosit $T$ atau sel $T$ berperan dalam system imun spesifik seluler. Sel tersebut juga berasal dari se asal yang sama dengan sel B. Pada orang dewasa sel t dibentuk dalam sumsum tulang tetapi proliferasi dan diferensiasinya terjadi di kelenjar timus. 90$95 \%$ sel T dalam timus tersebut mati, hanya $5-10 \%$ menjadi matang dan selanjutnya meninggalkan timus dan masuk dalam sirkulasi.

Faktor timus yang disebut timosin dapat ditemukan dalam peredaran darah sebagai hormone asli dan dapat mempengaruhi diferensiasi sel $\mathrm{T}$ di perifer. Berbeda dengan sel $B$, sel t terdiri dari beberapa subset sel dengan fungsi yang berlainan yaitu sel CD4+ ( Th 1, Th2 ), CD 8+ atau CTL atau Tc dan Ts atau Tr atau Th3. Fungsi utama system imun spesifik seluler ialah pertahanan terhadap bakteri yang hidup intraseluler, virus juga parasit dan keganasan. Sel CD4+ mengaktifkan sel Th1yang selanjutnya mengaktifkan sel makrofag untuk menghancurkan mikroba. Sel CD8+ memusnahkan sel terinfeksi.

\subsection{Latihan dan Sistem Imun}

Efek latihan terhadap sistem imun dapat dijelaskan karena adanya :

1. Interaksi sistem saraf pusat dan sistem imun

Aktifitas fisik aerobik mempengaruhi neuropeptide pada sistem saraf pusat dan darah tepi yang dapat merangsang meningkatkan fungsi imun.

2. Pengaruh nutrisi pada sistem imun Jumlah leukosit dalam sirkulasi meningkat secara nyata selama latihan dan besarnya meningkat berhubungan dengan intensitas dan durasi latihan. Peningkatan jumlah leukosit terutama pada jumlah granulosit. Latihan juga meningkatkan sirkulasi jumlah limfosit dan menyebabkan perubahan pada proporsi relative sel $\mathrm{T}$, sel $\mathrm{B}$ dan NK sel serta pada subset sel T (CD4 dan CD8 ). Setelah latihan jumlah leukosit total dan granulosit tetap meningkat selama beberapa jam, sedangkan jumlah limfosit menurun di bawah garis dasar sebelum kembali ke nilai preexercise. Perubahan angka pada jumlah lekosit dan limfosit selama latihan tidak lama dan kembali tipe $1 \mathrm{~T}$ sel ditekan di sirkulasi sementara produksi sel $\mathrm{T}$ tipe 2 tidak terpengaruh sehingga peran system imun seluler tipe 1 dalam melawan infeksi virus akut menjadi berkurang. Disamping itu IL-6 berperan juga dalam menekan kerja dari TNF- $\alpha$, hal ini menguntungkan karena berarti peran tipe 2 sel $T$ dalam menekan kerja system imun untuk mengatasi kerusakan jaringan dan inflamasi juga tertekan sehingga untuk latihan intensitas tinggi jangka panjang yang dilakukan secara teratur justru dapat menghambat berkembangnya kelainan kronis (Gleeson,2007).

\section{III.KESIMPULAN}

Pemberian rangsang fisik yang berulang pada tubuh akan menyebabkan proses adaptasi yang dapat mencerminkan peningkatan kemampuan fungsional tetapi jika besarnya rangsangan tidak cukup untuk proses pembebanan, maka tubuh tidak akan mengalami proses adaptasi.Sebaliknya jika rangsang terlalu besar yang tidak dapat ditoleransi oleh tubuh akan menyebabkan jejas dan mengganggu keadaan homeostasis pada sistem tubuh. Latihan intensitas tinggi dapat meningkatkan hormone epinephrine dan cortisol di plasma yang dikenal sebagai efek immunomodulator . Latihan dapat mempengaruhi hypothalamus untuk memproduksi ACTH oleh kelenjar adrenal dan berakibat meningkatkan produksi IL-6. Produksi IL-6 meningkatkan produksi IL-1 ra dan IL-10 bersamaan dengan CRP ( CReactive Protein). Peningkatan sitokin di atas dan produksi epinephrine dan cortisol pada latihan intensitas berat menyebabkan produksi tipe $1 \mathrm{~T}$ sel ditekan di sirkulasi sementara produksi sel $\mathrm{T}$ tipe 2 tidak terpengaruh sehingga peran system imun seluler tipe 1 dalam melawan infeksi virus akut menjadi berkurang. Disamping itu IL-6 berperan juga dalam menekan kerja dari TNF- $\alpha$, hal ini menguntungkan karena berarti peran tipe 2 sel $T$ dalam menekan kerja system imun untuk mengatasi kerusakan jaringan dan inflamasi juga tertekan sehingga untuk latihan intensitas tinggi jangka panjang yang dilakukan secara teratur justru dapat menghambat 
berkembangnya kelainan kronis. Dampak negatif dari latihan akan muncul khususnya pada latihan intensitas berat, seperti penurunan sistem imun sehingga seorang atlet akan lebih gampang mengalami infeksi. Kejadian infeksi pada para atlet yang sedang dalam pemusatan latihan sudah banyak dilaporkan berdasarkan penelitian yang sudah dilakukan sebelumnya, tetapi masih belum jelas aspek-aspek ilmiah manakah yang paling merusak sistem imun dan lebih rentan terhadap infeksi. Jadi respon imun pada tubuh sebagai akibat dari latihan belum diketahui dengan jelas.

Beberapa hasil penelitian belum ada kesepakatan mengenai beban dan bentuk latihan fisik yang meningkatkan atau menurunkan ketahanan tubuh. Secara umum penelitian menunjukkan bahwa latihan fisik intensitas tinggi menimbulkan kerusakan respon ketahanan tubuh, sedangkan pada laihan intensitas sedang belum ada kesepakatan dalam kesamaan hasil terhadap respon imun.

\section{DAFTAR PUSTAKA}

Bratawijaya Karen G, Iris R,2010, Imunologi Dasar, edisi ke 10 , Jakarta, Fakultas Kedokteran Universitas Indonesia.

Bente K P,; Exercise and Cytokines; immunology and Cell Biology (2000) $78,532-535$

Bompa, 1983; Theory and Methodology of Trainning The Key to Athlete Performance $3^{\text {rd }}$ ed; USA, Kendall/Hunt pub.comp

Bruunsgaard. $\mathrm{H}$, et al, Exercise Induced Increase in serum Interleukin-6 in humans is related to Muscle damage, Journal of Physiology (1997),499.3,pp 833-841

Fox E L, Bowers RW, Foss Ml,1993. The Physiological Basis for Exercise and Sport, $5^{\text {th }}$ ed. Madison: Brown\&Benchmark,pp.96,110-111,116.

Gleeson Michael, immune function in Sport and Exercise, Journal of Applied Physiology , August 2007 Vol.103 no 2 693-699
Gleeson Maree; Exercise Immunology; Immunology and Cell Biology, 2000, 78, 483-484; doi;10.1111

Heath,G.W et al; Exercise and The Incedence of Upper respiratory tract infections. Med Sci Sports Exerc. 23;152-157,1991.

Karen G,2010; Imunologi Dasar Edisi 10; Jakarta; Fakultas Kedokteran Universitas Indonesia, h.29-40.

Lamb D. R.,1984. Physiology of Exercise Responses \& Adaptations, $2^{\text {nd }}$ ed. New York: Mac Millan Publishing Comp.pp,10-11,13.

Mackinon LT, 1992. Exercise and Immunology. Cahmpaign; Human Kinetics Publisher Inc.

Mc. Ardle et al, 1981; Exercise physiology Energy, Nutrition and Human Performance; USA, Lea\&Febiger

Nieman Dc et al,1994. Effects of Long Endurance on Immune System Parameters and lymphocite Function in Experienced Marathoners. International of Journal of Sports Medicine,10;317323.

Nieman DC,et al; infectious Episodes in Runners before and After The los Angeles Marathon. Int $\mathrm{J}$ Sports med Phys. Fit.30;316-328,1990

Nieman DC, Exercise Immunology: Practical Applications; Int J Sports med,1997 Mar; 18 suppl 1: S91-100

Peters,E.M., and Batemen,E.D. Respiratory Tract Infections: and Epidemiological survey,S,Afr.Med.J.64: 582-584,1983.

Setiawan S,1995. Pengaruh Latihan Fisik Aerobik dan Anaerobik Terhadap Pola respon Ketahanan Tubuh. Disertasi. Universitas Airlangga Surabaya.

Spence et al; Incidence, Etiology, and Symptomatology of Upper Respiratory Illness in elite Athletes. Med Sci Sports Exerc, 2007 Apr,39(4);577-86. 